\title{
Fiscal Decentralization in the Western Balkan Countries, The Case of the Republic of Macedonia
}

\author{
Prof. Dr. Rufi Osmani \\ Faculty of Business and Economics, South East European University, Tetovo, Republic of Macedonia \\ Email: rufi.osmani@seeu.edu.mk
} Doi:10.5901/mjss.2014.v5n13p347

\begin{abstract}
The prolonged economic and political transition in the Western Balkan countries has left significant negative consequences on the functionality of the economic system. The enthusiasm seen from policymakers and citizens that the implementation of the economic liberalization and stabilization coupled with a lot of structural reforms would create functioning market economy and functioning institutions were not realized in a considerable level even after two decades of transition. Structural reforms essentially aimed to create functioning central and local institutions which would help the economy to achieve high economy rates whereas the citizens will get help in coping with the high cost of the transition in the function of enduring the increasing unemployment and poverty. In order for these economic, political and social objectives to be realized they were implemented among other reforms and reforms in the functioning of local democracy and growth of local financial autonomy. The paper aims to give an objective answer regarding the real level of fiscal decentralization and to recommend new ideas for advancing this process in perspective based on EU's best practices through a comparative approach of the level of fiscal decentralization in Macedonia compared to European Union countries and Western Balkan.
\end{abstract}

Keywords: Western Balkan, Republic of Macedonia, Fiscal decentralization, economic and political transition, structural reforms

\section{Introduction}

The process of transformation of the political and economic system of the former socialist countries to democratic political system and free market economy in the political and economic literature is identified as a process of political and economic transition.

The management of economies based on central planning in a historic process of transition to a market economy was mainly conducted with the assistance and surveillance of main international financial institutions. Scientific circles and the major international financial institutions achieved consensus for careful management of the key issues relating to economic liberalization, economic stabilization and structural reform that was duty for implementation in institutions of post-communist countries.

In scientific circles and in the major international financial institutions for careful management of the key issues relating to economic liberalization, economic stabilization and structural reform agenda implementation in institutions of post-communist countries that pass through a difficult process of comprehensive transformation of the political and economic sistem full compliance was achieved.

The role of international financial institutions and in particular the IMF and World Bank appear among the most important in terms of overcoming the difficulties of the transition in the framework of cooperation and surveillance of economic and fiscal reforms in transition countries.

During the current period of economic transition, international financial institutions provided considerable technical assistance and financial support to the national authorities of the countries of the Western Balkans in their efforts of building competent institutions in the function of creating a suitable environment for the functioning of the market economy and implementation and fiscal and economic reforms.

In most transition economies in the implementation of national economic programs harmonized and supported by the IMF and the World Bank reached positive results in terms of macroeconomic stabilization, a serious reduction of the fiscal deficit and partial realization of economic growth, reducing unemployment and poverty. Financial and fiscal reforms in the countries of the Western Balkans continue to be realized in the framework of meeting the Maastricht criteria and Copenhagen in the process of integration of these countries into the European union.

Fiscal reforms as an important process of economic and fiscal stabilization is closely associated with the political, social and ethnic cohesion towards the realization of a substantial and functional decentralization of a functional local autonomy.

There are serious differences between the different countries in the Western Balkans and the EU countries in 
terms of competencies and financial potential transferred as fiscal powers to local authorities. These differences are the result of the fact that a considerable number of countries analyzed implement local and regional territorial organization and have different levels of decentralized powers to local authorities.

The paper aims through a comparative analysis to measure the level of fiscal decentralization in Macedonia in relation to other countries of the Western Balkans and countries of European Union to give competent answers for the level of fiscal decentralization in Macedonia and to propose ideas for the advancement of this process as a prerequisite for the realization of a real financial autonomy of local authorities in Macedonia.

Besides the inadequacy of fiscal decentralization in Macedonia there is also a regional level of discrimination that is manifested as discrimination of rural municipalities in favor of urban and simultaneously takes dimensions of ethnic and political discrimination as a result of not implementing the law on equal regional development in terms of regional allocation of public capital investment.

Basic problems in the case of financial and fiscal decentralization in the Macedonia case relate to the inadequacy of the financial and fiscal potential delivered to the local authorities to successfully realize their competencies within the local political autonomy.

\section{Decentralization in the Western Balkans as Contrasted to the European Union}

The level of decentralization in terms of an increased autonomy of the local government and enabling it to provide local services at a lower cost at an increased quality for the citizens, implies delegated control over appropriate sources of finance as a guarantee that such services can be realized. Literature as well as practice on contemporary public finance shows a growing trend of finance for local and regional authorities as a precondition to provide higher autonomy in political and economic terms. In the case of the Western Balkan, the process of political and financial decentralization has met many problems and political hesitations, due to the fact that political and fiscal decentralization has not been analyzed from a functional point of view but rather from an ethnical point of view with the purpose of deepening the ethnical and economical discrimination of minorities in multiethnic societies such as Bosna and Hercegovina, Macedonia, Montenegro and Serbia.

Chart 1. Local Government Revenue as Share of GDP and Total Public Revenues in 2010

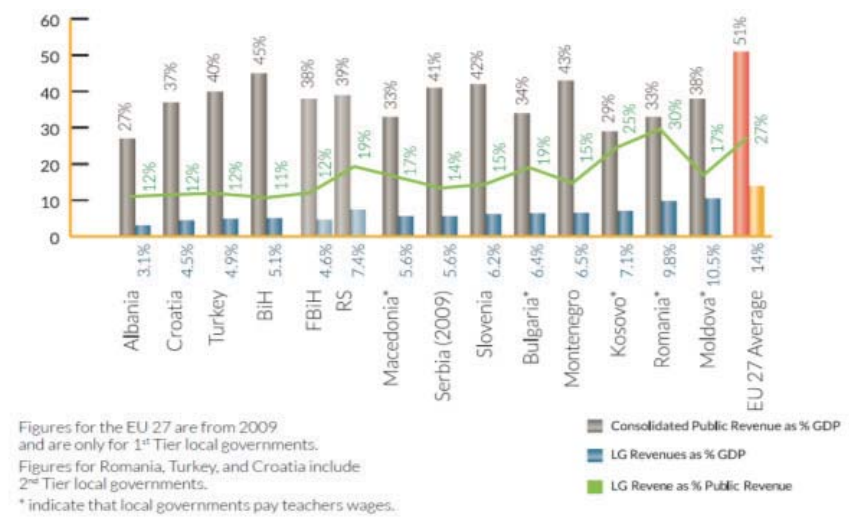

Source. NALAS (2011), p.22

The current level of fiscal decentralization in Macedonia (5.6\% of local public finance in proportion to the GDP and 17\% participation of the local public expenditure in the general amount of public expenditure), is at the level of only $62 \%$ of the average public consumption in the EU and as such is not sufficient for the realization of the actual competencies of local authorities, neither for increasing the quality of services provided by local authorities, nor to eliminate the gaps in the level of development of the different regions (in particular the communities dominated by ethnic Albanians). 
Chart 2. Local Government Revenue as Share of GDP and Total Public Revenues in 2010

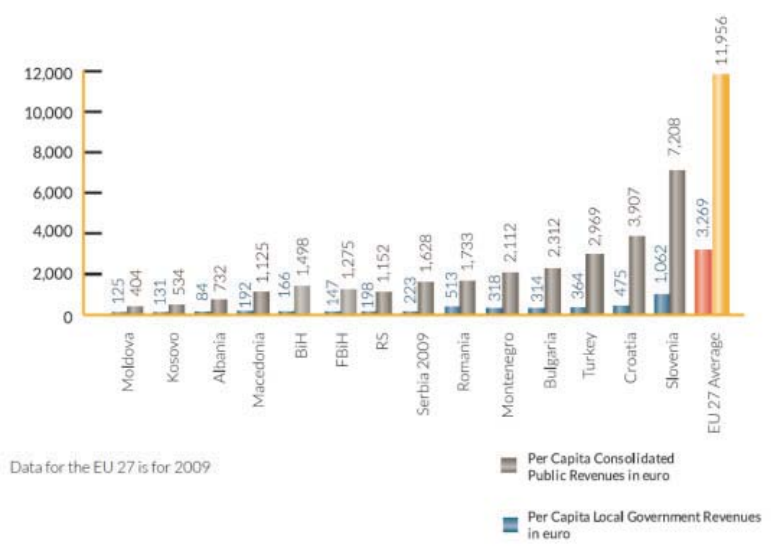

Source. NALAS (2011), p.23

The inadequate levels of fiscal decentralization have caused deep disparities among counties of the Western Balkans as well as compared to the EU average, analyzed as incomes per capita both on the local and national level. The lowest levels are evidenced in Moldova and Kosovo, while Macedonia with an average of 192 euro local public money per capita and 1.1125 euro per capita at the central government level has a medium average performance compared with the Western Balkan countries. The local fiscal performance per capita in Macedonia is at the level of $5.9 \%$ compared to the EU level and the national consumption per capita is at the level of $10.5 \%$ of the EU level. Such data are strong proove that the level of fiscal decentralization in Macedonia is well below the EU average.

\section{Sources of Local Public Finance Before and After 2001}

The internal ethnic conflict in Macedonia in 2001 produced the change of Macedonian Constitution and advanced the rights of minorities in particular the political rights of the Albanian community. Sources of financing for local authorities before and after 2001 are presented in table 1.

Table 1. Sources of finance for local authorities belore and after 2001

\begin{tabular}{|l|c|l|}
\hline \multicolumn{1}{|c|}{ Source of finance } & Before 2001 & \multicolumn{1}{c|}{ After 2001 } \\
\hline 1. Local taxes & Local & \multicolumn{1}{c|}{ Local $\%-0,2 \%$} \\
\hline Property taxes & $0,1 \%$ & \multicolumn{1}{c|}{$0 \%, 2 \%-3 \%, 4 \%-5 \%$} \\
\hline The tax of turnover of property & $3 \%$ & \\
\hline $\begin{array}{l}\text { The tax on property heritage : } \\
\text { First generation Second generation, Third generation, }\end{array}$ & $0 \%, 3 \%, 5 \%$ & \\
\hline 2.Local taxes & & \multicolumn{1}{c|}{} \\
\hline Communal taxes & Local (fix tariffs) & Local with margins \\
\hline Administrative taxes & Central & Local with margins \\
\hline 3.Tax income & Central & Marginally local \\
\hline Tax on personal income(PIT) & - & $3 \%$ \\
\hline Tax on additional value (VAT) & - & $3 \%-3,4 \%$ \\
\hline $\begin{array}{l}\text { 4.Grants from the } \\
\text { government of RM }\end{array}$ & No & $\begin{array}{l}\text { Block grants for education,Capital grants, } \\
\text { Grants for delegated competences }\end{array}$ \\
\hline 5.Debts & Central & Local \\
\hline 6.Other local income & Local & Local \\
\hline 7.Other income & Central & Local - Central \\
\hline
\end{tabular}

A comparative analysis of the sources of finance for local authorities before and after 2001, shows an additional growth of $3 \%$ of the tax on personal income and $3 \%$ of VAT meaning a nominal increase of only $12 \%$ in real public finance. These are the only sources that the local authorities manage independently from the central government in Skopje. 


\section{The Dynamics of Fiscal Decentralization in the Period 2002-2010}

The process of fiscal decentralization in financial and functional sense in Macedonia has recognized certain progress from 2002 until 2013. This progress was achieved with the direkt assistance of international institutions such as the World Bank, UNDP, USAID and is led by the Ministry of Local Government and the Ministry of Finance.

The increased growth of public money for local governance in Macedonia has affected the transfer of competencies in the area of primary and secondary education. Through this transfer to local authorities were transferred funds for payment of the salaries of education personnel and financial funds for school buildings as operating expenses.

This transfer represents increases of public money for over three times in benefit of the local authorities and that essentially has no meaning in the real growth of the financial and fiscal autonomy because the capital investments in the education sector remain central government competencies. Real growth of public finance at the local level in the case of Macedonia in the period 2002-2010 from 1.4\% to 2,6\% of GDP ranks Macedonia among the countries of Western Balkan with high centralization of public finance in favor of the central government.

Table 2 . Annual statement between GDP and municipalities revenues ( 2002-2010)

\begin{tabular}{|l|c|c|c|c|c|c|c|c|c|}
\hline \multicolumn{1}{|c|}{ Desc. /Year } & 2002 & 2003 & 2004 & 2005 & 2006 & 2007 & 2008 & 2009 & 2010 \\
\hline In billions of denars \\
\hline GDP & 240.283 & 258.369 & 272.462 & 295.052 & 320.059 & 353.786 & 411.728 & 409.100 & 423.862 \\
\hline Revenues of munic. & 3.388 & 4.440 & 4.952 & 5.573 & 8.035 & 9.430 & 21.037 & 23.139 & 23.779 \\
\hline Mun. rev as part of GDP (\%) & 1.410 & 1.718 & 1.818 & 1.889 & 2.511 & 2.665 & 5.109 & 5.656 & 5.610 \\
\hline \multicolumn{8}{|c|}{$\%$ of GDP } \\
\hline Tax revenues & 0.93 & 1.12 & 1.17 & 1.12 & 1.00 & 1.08 & 1.39 & 1.13 & 1.40 \\
\hline Non tax revenues & 0.09 & 0.08 & 0.11 & 0.08 & 0.35 & 0.27 & 0.28 & 0.26 & 0.30 \\
\hline Capital grants & & 0.02 & 0.03 & 0.01 & 0.03 & 0.01 & 0.04 & 0.17 & 0.37 \\
\hline Debts & 0.39 & 0.49 & 0.47 & 0.70 & 0.47 & 0.58 & 0.72 & 0.60 & 0.57 \\
\hline Sect. dotations & & & & 0.14 & 0.40 & 0.75 & 2.32 & 2.83 & 2.97 \\
\hline
\end{tabular}

Source: Authors own calculations basen on oficial statistical data

\section{Fiscal Discrimination and Underdevelopment of Municipalities of Different Regions: A Systemic Problem}

Besides the low level of fiscal decentralization generally a serious problem that affects the growth of regional disparities and devalues the current process of fiscal decentralization is the unfair allocation of financial resources to different municipalities of different regions in Macedonia. Numerous analysis made by foreign experts have ranked municipalities in Macedonia in 4 groups addressing the capital of country Skopje separately. The data presented in table 3 prove the systemic discrimination of municipalities ranked from level 1 to 3 and an extraordinary financial position for the district of Skopje.

Table 3. Basic Incomes in group of municipalities for the year 2008

\begin{tabular}{|l|c|c|c|c|c|c|c|}
\hline \multicolumn{1}{|c|}{ Description } & $\begin{array}{c}\text { Mun. - } \\
\text { Group I }\end{array}$ & $\begin{array}{c}\text { Mun. - } \\
\text { Group II }\end{array}$ & $\begin{array}{c}\text { Mun.- } \\
\text { Group III }\end{array}$ & $\begin{array}{c}\text { Mun. } \\
\text { Group IV }\end{array}$ & Skopje & Total & $\%$ \\
\hline Municipal tax & 30 & 66 & 78 & 89 & 162 & 425 & $2.39 \%$ \\
\hline Tax on property & 68 & 163 & 142 & 319 & 568 & 1260 & $7.09 \%$ \\
\hline Turnover tax & 222 & 429 & 355 & 753 & 1520 & 3279 & $18.46 \%$ \\
\hline Public lightning & 182 & 373 & 356 & 404 & 441 & 1756 & $9.88 \%$ \\
\hline Company tax & 36 & 114 & 90 & 147 & 78 & 465 & $2.62 \%$ \\
\hline Tax for construction land & 68 & 225 & 373 & 992 & 3736 & 5394 & $30.36 \%$ \\
\hline Other tax'es & 22 & 60 & 79 & 152 & 171 & 484 & $2.72 \%$ \\
\hline Administrative tax & 50 & 111 & 211 & 149 & 187 & 708 & $3.98 \%$ \\
\hline VAT & 499 & 517 & 741 & 622 & 227 & 2606 & $14.67 \%$ \\
\hline Transfers from the fond for public roads & 205 & 242 & 345 & 362 & 236 & 1390 & $7.82 \%$ \\
\hline Total revenues & 1382 & 2300 & 2770 & 3989 & 7326 & 17767 & $100.00 \%$ \\
\hline$\%$ & $7.78 \%$ & $12.95 \%$ & $15.59 \%$ & $22.45 \%$ & $41.23 \%$ & $100.00 \%$ & \\
\hline
\end{tabular}

Source: Authors own calculations based on official statistical data 
Analysis conducted by USAID and UNDP expert argues that the favored position of Macedonia's capital Skopje and utilization of over $41 \%$ of financial funds realized in all financial lines particularly is affected by the fact that all national institutions are allocated in Skopje, great economic investments are realized in economic free zone in the region of Skopje has had direct effect on the fiscal potential of the capital of the country. Municipal and regional disparities in terms of fiscal decentralization move from - $4 \%$ for the municipalities listed in Group 3 in order to achieve - $11 \%$ for municipalities listed in group 1 and 2. Existing system of public financing offers $+24 \%$ more public finance for capital Skopje at the local level despite the fact that in Skopje lives only 25\% of the population of Macedonia.

Table 4. Municipal revenues

\begin{tabular}{|l|c|c|c|c|c|c|c|}
\hline Gr. Of munic. & No. of munic & Popul. & $\begin{array}{c}\% \text { of } \\
\text { popul }\end{array}$ & Budget per capita & $\begin{array}{c}\text { Basic } \\
\text { budget }\end{array}$ & $\begin{array}{c}\% \text { of budget } \\
\text { revenues }\end{array}$ & Disparity \\
\hline Group I & 19 & 342,016 & $17 \%$ & $1,382.00$ & $472,739,479.00$ & $6 \%$ & $-11 \%$ \\
\hline Group II & 19 & 542,826 & $27 \%$ & $2,300.00$ & $1,248,341,641.00$ & $16 \%$ & $-11 \%$ \\
\hline Group III & 19 & 254,799 & $13 \%$ & $2,770.00$ & $705,844,786.00$ & $9 \%$ & $-4 \%$ \\
\hline Group IV & 18 & 375,980 & $19 \%$ & $3,988.00$ & $1,499,243,172.00$ & $20 \%$ & $1 \%$ \\
\hline Skopje & 10 & 506,926 & $25 \%$ & $7,325.00$ & $3,713,321,231.00$ & $49 \%$ & $24 \%$ \\
\hline Total & 85 & $2,022,547$ & $100 \%$ & $3,777.00$ & $7,639,490,309.00$ & $100 \%$ & \\
\hline
\end{tabular}

Source: USAID, 2008

These deep fiscal disparities are systematic and have significantly canceled the positive effects of the beginning of the implementation of local autonomy and decentralization of public finance since the systemic changes of 2002.

Such a discriminatory approach, not only deepens fiscal disparities among rural and urban municipalities, but also deepens the gap in development among regions depending on their ethnic structure. It should be mentioned that regions that are inhabited mostly by ethnic Albanians are additionally discriminated by the unequal distribution of public investments finance from governmental grants or from international sources but via the governmental institutions.

\section{Conclusions and Recommendations}

$>$ The low level of local public consumption in Macedonia (only 5-10\% of the EU average), imposes the need for furthering reforms in political decentralization followed by serious decentralization of public money from central to local and regional levels.

$>$ A decrease in the number of municipalities and the creation of functional municipalities with sufficient economic and developmental potentials, but maintaining an adequate territorial division, would enable such municipalities to have sufficient sources of finance as a precondition for financial and fiscal consolidation of local authorities in general and those in discriminated municipalities in particular.

$>$ In order to eliminate the great developmental disparities among regions and ethnical groups a new system for fiscal equilibration that would favor the underdeveloped rural municipalities and disable future disparities is needed.

$>$ An increase in the level of block dotations from VAT from $4 \%$ to at least $20 \%$ on a medium range by modifying the formula for VAT allocation would stabilize local public budges and create opportunities for productive capital investments at the local level.

$>$ A more adequate implementation of the Law for equal regional development and the investments of at least 70-100 million Euros annually in projects of benefit for the less developed municipalities and regions would help in eliminating the expressed disparities among the regions and would create opportunities for equal development in the future.

> The determination of new criteria for the allocation of block dotations by implementing transparent and public procedures based on functions and not institutions, would provide a more just allocation and would contribute to the elimination of the institutional corruption and the misuse of huge public financial funds.

> An undertaking of the debt of local authorities by the central government, combined with the elimination of the limitations for taking loans from relevant international institutions by the local authorities would support the process of stabilization and fiscal development of local authorities in Macedonia in the future. 


\section{References}

Nalas,Report , Fiscal Decentralization Indicators for SEE 2006-2012, 2014

The World Bank ,SEE,Regular Economik Report,Britle Recovery,2014, The World Bank,SEE Municipal Finance Review Local Government Finance, the Western Balkans 2013

The World Bank, Dillinger, William "Intergovernmental Fiscal Relations" in Laursen, Thomas, Current Issues in Fiscal Reform in Central Europe and the Baltic States,2005,

Tony Levitas ,MDW/USAID , Report of fiskal decentralization 2008 , Skopje SEEU,FBA, Tetovo, economic status and development, 2008

Rufi Osmani ,,The Ohrid Agreement ten years after,achievements, problems and challenges, The OFA ten years after, SEEU ,Tetovo, 2011,

Rufi Osmani „Budget management 2009-2012 of Municipality of Gostivar, 2012 ( www.rdk.org.mk) , Undp, George State University , Musharraf R. Cyan, Jorge Martinez-Vazquez, Andrey Timofeev,, Financing equitable service delivery for all citizens:Skopje, 2009

World Bank, FYR Macedonia: Decentralization Status Report. Report No. 24305-MK. Department, Europe and Central Asia Region, Washington,2005,

Schlumber-Sema "Technical Assistance to Ministry of Finance of FYROM on Fiscal Decentralization: Municipal Debt Assessment",Skopje , 2004.

Nikolov Marjan „Fiskal decentralization in FYROM,, last trendes , CEA , Skopje , 2005

Local Government Reform Program (LGRP) and USAID, Strategic Plans for Local Economic Development, Skopje, 2005 